\title{
ФОРМУВАННЯ ГРОМАДСЬКОГО ТА НАУКОВОГО СВІТОГЛЯДУ А. ЯКОВЛІВА
}

Анотація: у статті розглядаються фактори та процеси, які сприяли становленню А. Яковліва як потужного украӥнського науковия, громадського та політичного діяча. Основна увага приділена вивченню студентських років подвижника. Охарактеризовано особливості його навчання у Дерптському (Тартуському) університеті та вплив на коло його наукових інтересів професора М. Дьяконова. Досліджено й уточнено доробок А.Яковліва у галузі археологічних досліджень. Особливе місие відведено висвітленню взаємовідносин А.Яковліва та Ф. Матушевського в їхні студентські роки й аналізу діяльності створеної ними Дорпатської української студентської громади.

Ключові слова: А. Яковлів, ХІІ Археологічний зӥзд, Дерптський (Тартуський) університет, Дорпатська українська студентська громада

Андрій Іванович Яковлів належить до плеяди замовчуваних у радянські часи постатей української історії першої половини ХХ ст. Сучасній науковій громадськості він відомий, у першу чергу, як активний учасник національно-демократичної революції 1917-1920 рр., учений-правознавець, засновник багатьох еміграційних українських осередків. Висвітлення його теоретичної діяльності має важливе значення як для історичної, так і для юридичної української науки. У той же час практична робота А.І. Яковліва в уряді Центральної Ради та на посаді ректора Українського вільного університету ставить його в один ряд 3 відомими українськими політиками та громадськими діячами початку XX ст.

Варто відзначити, що комплексного дослідження, присвяченого А.І. Яковліву, не існує, оскільки його творча спадщина ще не опрацьована у повній мірі. Однак окремі аспекти його діяльності висвітлені сучасними науковцями досить потужно. Так, політико-правовим поглядам вченого присвячене дисертаційне дослідження та низка статей Т. Маньгори. Його діяльність під час українських національно-визвольних змагань розглядалася у роботах Я. Попенка, В. Потульницького, В. Ульяновського. Еміграційний період висвітлений дослідниками: Т. Андрусяк, Н. Стецюк, С. Наріжним, М. Петрів, М. Савкою. І. Верба, В. Верстюк, І. Підкова, Г. Стрельський, А. Трубайчук, І. Усенко подають коротку інформацію про біографію А.І. Яковліва на сторінках довідкових видань. Всебічно дослідити життєвий шлях та основні вектори діяльності науковця спробував А.Петрик. Проте поза увагою більшості дослідників залишився період становлення А.І.Яковліва як науковця та громадського діяча, котрий припадає на його студентські роки.

\footnotetext{
* Токар Наталія Миколаївна - кандидат історичних наук, доцент кафедри історії України Центральноукраїнського державного педагогічного університету імені Володимира Винниченка (Кропивницький, Україна); ORCID: https://orcid.org/0000-0002-2263-2338; e-mail: vega0604@ukr.net
} 
Про дитинство А.І. Яковліва відомо небагато. Він народився 28 листопада (11 грудня) 1872 р. у місті Чигирин, Київської губернії у родині губернського секретаря Івана Юхимовича Яковліва. На момент його народження матері - Марії Прохорівні - було 19 років, а батькові - 44 роки (це був його другий шлюб). Багатодітна сім'я мешкала у своєму будинку на Дворянській вулиці ${ }^{1}$.

Залишається питанням: де він отримав початкову освіту. Т. Маньгора стверджує, що він навчався у початковій школі у Черкасах протягом 1886-1890 pp. ${ }^{2}$ Але тоді виходить, що він вступив до школи лише у 14 років. У свою чергу, А. Петрик стверджує, що А. Яковлів у 1886 р. закінчив повітову чигиринську школуз ${ }^{3}$ Більшість дослідників при вивченні цього питання спиралися на матеріали іменного фонду А.Яковліва, що зберігається у Центральному держархіві вищих органів влади та управління України у м. Києві. У фонді $4438^{4}$ міститься документ під назвою «Автобіографія А. Яковліва». Однак при його опрацюванні виявилося, що цей документ, який складається з двох частин - трьох сторінок машинописного тексту та трьох сторінок рукописного, не $є$ автобіографією. Перша його частина ймовірно була написана у 1930 р. і більше схожа на характеристику людини, яка обирається на посаду. Таке припущення є цілком логічним, оскільки саме у 1930 р. А. Яковліва було обрано ректором Українського університету в Празі. Друга, рукописна частина документу, являє собою статтю до 70-річчя науковця, написану на початку 1943 р., а іï авторство не встановлено. У будь-якому випадку ці документи не містять інформації про дитинство А. Яковліва.

Достеменно відомо, що протягом 1890-1894 pp. А.Яковлів навчався у Київській духовній семінарії, яку закінчив 3 дипломом І ступеня ${ }^{5}$. Незважаючи на те, що Київська духовна семінарія була головною школою, яка готувала кандидатів у священство для Київської єпархії, чимало її випускників стали згодом відомими не тільки церковними, але й громадськими та культурними діячами.

Упродовж 1894-1898 рр. А. Яковлів працював учителем у Черкасах 6 . Про цей період його життя відомостей практично немає. Однак можна висловити цілком логічне припущення, що амбітний допитливий юнак мріяв про здобуття вищої освіти і тому, завдяки своїй наполегливості, у 1898 р. був зарахований на правничий факультет університету у Дерпті. Цей університет було обрано не випадково - з 1897 р. сюди було дозволено приймати вихованців духовних семінарій (в інші університети, за винятком Варшавського й Томського, їх не брали). Більшість студентів-українців у Дерптському університеті якраз і становили випускники духовних семінарій з України.

Саме період навчання А. Яковліва у цьому закладі - з 1898 по 1902 рр., на наш погляд, став головним у формуванні наукового світогляду майбутнього вченого. Це було зумовлено своєрідною атмосферою Юрьївського університету (протягом 1893-1918 рр. заклад мав

\footnotetext{
${ }^{1}$ Маньгора Т.В. Політико-правові погляди А.І. Яковліва: дис... канд. юрид. наук: 12.00.01. Київ, 2015. С. 53.

${ }^{2}$ Ibid. C. 56.

${ }^{3}$ Петрик А. Андрій Яковлів (1872-1955): нариси життя та діяльності // Український історичний збірник. 2011. Вип. 14. С. 267.

${ }^{4}$ Центральний державний архів вищих органів влади та управління України (ЦДАВО України). Ф. 4438. Оп. 1. Спр. 5.6 арк.

${ }^{5}$ Ibid. Арк. 1.

${ }^{6}$ Ibidem.
} 
назву Юрьївський у зв'язку з перейменуванням Дерпта на Юрьїв; нині - це Тартуський університет). Тут ще з XIX ст. сформувалася нехарактерна для Російської імперії, до складу якої входили естонські землі, система викладання. Дерптські студенти мали змогу обирати дисципліни, самостійно визначати строк навчання, який залежав від успішної здачі іспитів, і бути членом студентської корпорації. Обравши факультет, студент одразу визначався 3 головною спеціальністю, у залежності від якої складався навчальний план слухача. Адже кожну спеціальність очолював професор, навколо предмету якого групувались інші другорядні та допоміжні дисципліни. Така організація навчального процесу давала можливість викладачу приділяти увагу роботі кожного студента, оскільки кількість останніх не перевищувала 20 осіб ${ }^{7}$.

А. Яковлів обрав курс історії західноруського та європейського права під керівнищтвом професора М. Дьяконова - автора фундаментальних праць 3 історії держави і права Київської Русі «Влада московських государів» та «Нариси суспільного і державного ладу Давньої Русі (до кінця XVII ст.) ${ }^{8}$. Під впливом ідей професора А. Яковлів під час практики (1901-1902 рр.) старанно вивчав документи Варшавського головного архіву, Варшавської казенної палати, Варшавських бібліотек. Опрацьовані архівні матеріали охоплювали історію Черкаського замку та його околиць (у тому числі й рідного А. Яковлєву Чигирина) i були покладені в основу його дисертаційного дослідження «Черкаський господарський замок і повіт у XV-XVII ст.».

Ще одним напрямом діяльності молодого науковця стали археологічні дослідження. Шукаючи на канікулах додаткового заробітку, влітку 1901 pp. А. Яковлів працював на будівництві залізниці Варшава-Каліш9․ Під час прокладання залізниці, яке розпочалося ще 1898 р., робітники неодноразово знаходили старожитності та кістки. Спеціальної експедиції, яка б здійснювала попередні розкопки, опрацьовувала знайдені артефакти та дбала про їхню подальшу долю, у кошторисі передбачено не було. Тому значну частку цієї роботи взяв на себе А.Яковлів, який розумів необхідність опису, дослідження та збереження знайдених матеріалів. Незважаючи на те, що він не мав належного досвіду, про що сам зізнався під час доповіді на археологічному з'їзді у Харкові 1902 р., молодий науковець намагався якісно виконати роботу ${ }^{10}$.

На окремих ділянках прокладання залізниці вимагало знесення цілих пагорбів, які на думку науковців, могли бути насипними курганами та потребували ретельного дослідження. Так, під час зрізу одного з таких насипів А. Яковлів виявив два заглиблення, заповнені червоною вохрою, та людські рештки. Не володіючи методикою опрацювання останків, робітникам вдалося зняти лише три кістяки, хоча всього, на думку А. Яковліва, їх було вісім. Окрім кісток у похованні було знайдено кремнієві знаряддя, які дослідник класифікував як наконечники стріл та ножі ${ }^{11}$. Апелюючи до досліджень Л.Нідерле,

\footnotetext{
${ }^{7}$ Соколова Н. Фахова підготовка студентів у Дерптському університеті (1803-1917 рр.) // Часопис української історії. 2018. Вип. 37. С. 105.

${ }^{8}$ Дьяконов М.А. Очерки общественного и государственного строя древней Руси. Москва-Ленинград, 1926. $402 \mathrm{c}$.

${ }^{9}$ Маньгора Т.В. Політико-правові погляди А.І. Яковліва... С. 54.

${ }^{10}$ Яковлев А. Несколько слов по поводу случайных археологических находок при постройках железных дорог // Ученые записки Харьковского университета. 1901. Кн. 4. С. 37-38.

${ }^{11}$ Яковлев А. Плоские могилы каменного века на р. Чир в Донской области // Труды Харьковского предварительного комитета по устройству ХІІ археологического съезда. Харьков, 1902. Т. 1. С. 145.
} 
А. Яковлів припустив, що знайдені поховання можна віднести до найдавнішого періоду існування людства ${ }^{12}$, однак брак належної підготовки не дозволив йому аргументувати свої висновки.

1900 р. будівництво тривало, і біля села Скотоватого Бахмутського повіту Катеринославської губернії лінія залізниці зачепила декілька курганів. А. Яковлів знову взявся керувати розкопками. Однак він не мав не лише належного досвіду, а й професійної команди: розкопки здійснювалися звичайними робітниками-землекопами, які працювали на будівництві цієї ж залізниці. Саме тому під час розкопок двох перших курганів всі знахідки були ушкоджені, оскільки їх разом з землею викинули до насипу. Серед ушкодженого матеріалу знаходились окремі сегменти кістяків, уламки прикрас і гончарних виробів.

При розкопках наступного кургану робітники під керівництвом А. Яковліва діяли обережніше і їм вдалося виявити під насипом поховання. Проте внаслідок того, що некваліфіковані землекопи, всупереч наказу керівника, вивертали великі пласти землі, всі кістяки знову були ушкоджені. Теж саме трапилося і з супроводжуючими матеріалами: цілісність майже всіх глиняних виробів, знайдених у похованні, була порушена. Не дивлячись на це, А. Яковлів опрацював уламки глиняного посуду і навіть виділив та описав чотири типи орнаменту, які найбільш часто зустрічалися серед уламків ${ }^{13}$. Однак датувати знайдені матеріали досліднику не вдалося.

На жаль, більша частина знахідок (кістяки, кераміка) були втрачені для науки. Лише окремі артефакти, переважно зброю, А. Яковлєву вдалося зберегти, зробивши їх частиною своєї особистої колекції. Щоденники розкопок, які дослідник вів вельми ретельно, він надіслав до Попереднього комітету археологічного з'їзду у Харкові. А незабаром його запросили виступити перед учасниками XII Археологічного з'їзду, який проходив з 15 по 27 серпня 1902 р.

у своїй доповіді, окрім ознайомлення слухачів з результатами своїх археологічних розвідок, А. Яковлів підняв низку гострих питань, важливих для розвитку археологічної науки. Так, він звинуватив керівництво залізниці у недотриманні постанови Міністерства шляхів сполучення про захист історичних пам'яток. Бажаючи зменшити витрати, підрядники не вносили до кошторису витрати на супроводжуючі дослідження пам'яток, а також не бажали витрачати час і кошти на доправлення знайдених артефактів до найближчих філіалів Археологічного товариства. Це призводило до руйнівних наслідків більша частина знайдених матеріалів була практично знищена самими ж робітниками, які не розуміли наукової цінності знахідок. А. Яковлів навів яскравий приклад такого недбальства: під час розкопок біля річки Чир він побачив, як один робітник намагався висікти вогонь зі знайденого кремінного ножа, а інший, надягнувши на палку кам'яну «булаву», знайдену у похованні, закинув її у поле, «щоб побачить, чи високо вона швигоне» ${ }^{14}$.

\footnotetext{
${ }^{12}$ Ibid. C. 146

${ }^{13}$ Яковлев A. Раскопки кургана у с. Скотоватого Бахмутского уезда Екатеринославской губернии в августе 1900 г. // Труды Харьковского предварительного комитета по устройству XII археологического съезда. Харьков, 1902. Т. 1. С. 186.

${ }^{14}$ Яковлев А.И. Плоские могилы на реке Чир в Донской области и археологические находки при постройке железных дорог // Труды Харьковского археологического съезда. Харьков, 1902. С. 130.
} 
Молодий ентузіаст був переконаний, що подібне відбувається не тільки на будівництві залізниці Варшава-Каліш, а й на більшості будівництв Російської імперії. Єдиним дієвим способом боротьби з подібною безвідповідальністю А. Яковлів вважав встановлення жорстокого контролю з боку державних органів над роботою будівничих компаній.

Результати археологічних досліджень А. Яковлєва були опубліковані у збірнику «Труды Харьковского предварительного комитета по устройству XII археологического съезда» у вигляді статті «Плоские могилы каменного века на р. Чир в Донской области» та двох повідомлень: «Раскопки кургана у с. Скотоватого Бахмутского уезда Екатеринославской губернии в августе 1900 г.» і «Несколько слов по поводу случайных археологических находок при постройках железных дорог». Однак у подальшому археологічні дослідження не входили до кола наукових інтересів А. Яковліва.

У стінах Дерптського університету відбулося й остаточне оформлення громадянської позиції А. Яковліва. Варто відзначити, що значний вплив на їі формування справив близький друг А. Яковліва Ф. Матушевський. Вони разом навчалися у Київській духовній семінарії, а потім вчителювали у Черкасах. Ще під час навчання в семінарії Ф. Матушевський був активним членом українських гуртків, товаришував з С. Єфремовим, В. Доманицьким, О. Лотоцьким, а у 1897 р. вступив до Загальноукраїнської безпартійної організації. Тому цілком очевидно, що одразу після вступу до університету Ф. Матушевський розгорнув активну громадську діяльність, долучивши до неї свого товариша. Юнаки оселилися на Техельферській вулиці і вже незабаром на їній квартирі збиралися українці з різних навчальних закладів міста.

Дерптський університет - єдиний вищий навчальний заклад Російської імперії, де навчалися політично неблагонадійні студенти, відраховані з вишів через участь у студентському політичному $\mathrm{pyci}^{15}$. Тому цілком закономірним було проникнення до студентського середовища політичних ідей різного спрямування. I якщо серед російських студентів найбільшої популярності набув соціал-демократичний рух, то у середовищі українського студентства переважали націоналістичні погляди. Свідома національна позиція українських студентів набула організаційного оформлення у 1899 р., коли Ф. Матушевський та А. Яковлів заснували Дорпатську українську студентську громаду. До її складу входило близько 20 чоловік. Головою громади було обрано Ф. Матушевського, заступником - А. Яковліва, секретарем - В. Козловського, скарбником - С. Макрі. Окрім них членами громади були Павло Горянський (пізніше вчитель у Криму, автор спогадів про Лесю Українку), Іван Білінський, Всеволод Козловський (у майбутньому журналіст, секретар посольства Української Народної Республіки в Берліні), Максим Синицький (згодом громадський діяч, організатор банків, кооперативів, видавництв, клубів, бібліотек, виставок тощо), Петро Баскевич (пізніше інспектор народних шкіл на Поділлі), Леонід Дложевський, Семен Кравців та ін. Контакти з громадою підтримували українці, що проживали в Тарту, зокрема приват-доцент фінансового права в університеті Орест Остроградський і професор політичної економії й статистики Олександр Миклашевський

Політична програма Дорпатської громади була викладена у Статуті та передбачала

\footnotetext{
${ }^{15}$ Соколова Н. Фахова підготовка студентів у Дерптському університеті (1803-1917 рр.)... С. 103.

${ }^{16}$ Ісаков С.Г. Українські студенти в Тартуському університеті XIX - початку XX ст. // Український історичний журнал. 2005. № 1. С. 77.
} 
розширення конституційних прав населення держави, можливість отримання освіти рідною (українською) мовою, видавництво українською мовою літератури та періодичних видань. Щодо політичного устрою українських земель, то найбільш придатним члени громади вважали автономію України в межах її національної території у складі Росії ${ }^{17}$.

Наявність політичної складової у програмовому документі автоматично свідчила про нелегальний статус громади. Тому від її учасників вимагалася сувора конспірація. Члени громади збиралися по суботах на спільній квартирі А. Яковліва та Ф. Матушевського, зазвичай по обіді, щоб не привертати увагу поліції. На засіданнях читали реферати та доповіді, присвячені проблемам українського життя, культури, ідеологічним питанням За спогадами А. Яковліва, статут, Як таємний документ, зберігався тут же, у спеціальній схованці - маленькому дерев'яному пуделку з-під чаю, в якому А. Яковлів зробив подвійне дно ${ }^{18}$.

Головним напрямом діяльності організації став пропагандистський - члени громади ставили собі за мету популяризувати українську культуру, влаштовуючи благодійні вистави та творчі вечори. Так, наприкінці лютого, за традицією, громада відзначала день Т. Шевченка. Перші роковини організували наприкінці лютого 1899 р. у помешканні на Техельферській, де А. Яковлів виголосив реферат на тему «Культурно-освітній рух у Галичині та на Буковині» ${ }^{19}$. у 1900 р. в дні Т. Шевченка взяла участь Л. Українка. Вона гостювала у брата М. Косача, який навчався в Тартуському університеті ${ }^{20}$.

11 листопада 1901 р. у великому залі «Бюргермуссе» силами членів громади було поставлено п'єсу класика української драматургії М. Кропивницького «Невільник». Навколо цієї благодійної вистави вдалося обєднати майже всіх українців, що проживали в Тарту. Вона принесла організаторам чималі кошти - 3500 рублів, які було передано на допомогу нужденним студентам-українцям. Аналогічні заходи влаштовувалися й у наступні роки. Так, 5 листопада 1902 р., у тому ж залі, було поставлено відому драму I. Карпенка-Карого «Бурлака».

Члени Дорпатської громади підтримували зв'язки 3 іншими нелегальними студентськими організаціями, особливо 3 грузинським земляцтвом і польським студентським соціалістичним товариством та брали участь у студентських виступах 18991902 рр. у Тарту ${ }^{21}$.

У 1903 р. через сімейні та матеріальні обставини А. Яковлів повернувся до України та через рік склав державний іспит й отримав диплом першого ступеня в університеті Св. Володимира в Києві. Протягом 1905-1907 pр. він активно та наполегливо вивчав українське право, був обраний членом Українського Наукового Товариства й управи київської «Просвіти». Його роботи історичного характеру («Бунт черкасців і каневців у 1536 році. Нарис з історії українських міст», «Намісники, державці і старости господарського замку Черкаського в XV-XVI ст.», «3 історії реєстрації українських козаків») друкувалися в журналі «Україна» 22 .

\footnotetext{
${ }^{17}$ Яковлів А. Українська студентська громада в Дорпаті // 3 минулого. Т. ІІ. Варшава, 1939 (Праці Українського наукового інституту. T. XLIX). С. 167.

${ }^{18}$ Ibid. C. 164.

${ }^{19}$ Яковлів А. Українська студентська громада в Дорпаті... С. 165.

${ }^{20}$ Ісаков С.Г. Українські студенти в Тартуському університеті XIX - початку XX ст.... С. 77.

${ }^{21}$ Ibid. C. 78

${ }^{22}$ Маньгора Т.В. Політико-правові погляди А.І. Яковліва... С. 55.
} 
Остаточне формування політичних і громадянських поглядів А. Яковліва, на думку більшості дослідників, відбулося під час стажування у Варшаві 1907 р., де він знайомиться 3 польськими суспільними націоцентричними настроями. У листуванні з Ф. Матушевським вчений описує враження від Варшави та їі мешканців у піднесених тонах і відзначає, що незважаючи на заходи влади, поляки зберігають власну мовну та культурну ідентичність. Ідеї, які сповідувала Дорпатська громада - «українізація мас» шляхом впровадження української мови у повсякденному спілкуванні, видання україномовної періодики, націоналізація театру та літератури - мають бути досягнуті лише шляхом активної просвітницької роботи національно орієнтованої інтелігенції серед інертного та несвідомого населення «Великої України». Тільки так, вважав діяч, можна відійти від «комплексу малоросійства» і добитися культурної української автономії, яка б мала стати проміжним етапом до самостійності культурної та, у віддаленій перспективі, політичної апогею змагань свідомих українців ${ }^{23}$. Громадська позиція В. Яковліва простежується у його публіцистичних працях, що регулярно друкувалися на сторінках «Громадської Думки» (пізніше «Ради»).

Отже, фундаментальна основа наукового світогляду А. Яковліва була закладена під час навчання у 1898-1902 pp. на юридичному факультеті Дерптського (Тартуського) університету, де, завдяки впливу німецької освітньої традиції, сформувалась унікальна для Російської імперії система фахової підготовки майбутньої еліти. Під керівництвом професора М. Дьяконова молодий науковець підготував дипломну роботу «Черкаський повіт у XV-XVI ст.». T. Маньгора стверджує, що після закінчення Дерптського університету обдарованому та здібному А. Яковліву пропонували залишитися на кафедрі історії та права для підготовки до професорського звання. Незважаючи на те, що звання професора він так і не отримав, всі його праці відзначалася грунтовністю, широкою джерельною базою й аргументованістю, а потужний потенціал науковця яскраво проявився у його викладацькій діяльності в державних і навчальних установах Києва.

Формування громадських і політичних поглядів А. Яковліва, на нашу думку, відбулося за активної участі Ф. Матушевського, з яким вони разом навчалися у Київській духовній академії та у Юрьївському університеті. Старший на три роки, Ф. Матушевський став головним ініціатором створення Дорпатської української громади, яка обєднала навколо себе всіх свідомих студентів-українців Тарту. Під впливом молодого ентузіаста сформувалась активна громадянська позиція А.Яковліва як громадського діяча національно-автономістського спрямування, яка згодом проявилася у його політичній діяльності під час і після національно-демократичної революції 1917-1920 р.

Nataliia Tokar

\section{Formation of A. Yakovliv's Public and Scientific Worldview}

Abstract: The article examines the process of forming the scientific and public worldview of Andriy Yakovliv - a famous Ukrainian historian of law, an active participant in the national

\footnotetext{
${ }^{23}$ Петрик А. Андрій Яковлів (1872-1955): нариси життя та діяльності... С. 264.
} 
democratic revolution of 1917-1920, a member of the Central Council, founder of many Ukrainian emigration centers, rector of the Ukrainian Free University (Prague).

The main attention is paid to the study of his student years, which were not the subject of a special study of Ukrainian scientists. The peculiarities of the educational process at the University of Dorpt (Tartu), where A. Yakovliv studied during 1898-1902, are described, successfully pass exams, and be a member of a student corporation. Having chosen the faculty, the student was immediately determined by the main specialty, which was headed by a professor, around the subject of which other secondary and auxiliary disciplines were grouped. A. Yakovliv chose a course in the history of Western Russian and European law under the guidance of Professor M. Dyakonov - the author of fundamental works on the history of the state and law of Kievan Rus, which determined the scope of his further scientific interests.

The article also covers A. Yakovliv's guide to archeological excavations that took place in the summer of 1900-1901 during the construction of the Warsaw-Kalisz railway. Despite the lack of proper experience in the field of archaeological research, the scientific reports of the young enthusiast attracted the attention of professional archaeologists and the report of A. Yakovliv was heard at the XII Archaeological Congress, which took place in 1902 in Kharkiv.

A special place in the article belongs to the coverage of the relationship between A. Yakovliv and F. Matushevsky - public figure, publicist, literary critic. Their friendship began while studying at the Kyiv Theological Seminary and lasted a lifetime. While studying at the university, they created an illegal Derpat Ukrainian student community, which included about 20 people. The community's charter provided for the expansion of constitutional rights, the possibility of receiving education in the Ukrainian language, and the publishing of literature and periodicals in the Ukrainian language. As for the political system of the Ukrainian lands, the members of the community considered the autonomy of Ukraine within its national territory within Russia to be the most suitable. Members of the Dorpat community maintained contacts with other illegal student organizations and participated in student demonstrations in 1899-1902 in Tartu.

Keywords: A. Yakovliv, XII Archaeological Congress, Derpat (Tartu) University, Derpat Ukrainian student community 